\title{
HUBUNGAN ANTARA ETIKA BERPERILAKU DENGAN KEMAMPUAN BERPIKIR LOGIS DAN KONFORMITAS PADA SISWA SEKOLAH MENENGAH PERTAMA DI SIDOARJO
}

\author{
Rosyikhotul Ilmiyah \\ Bimbingan Konseling, Fakultas Ilmu Pendidikan, Universitas Negeri Surabaya \\ rosyikhotulilmiyah16010014031@mhs.unesa.ac.id \\ Eko Darminto \\ Bimbingan Konseling, Fakultas Ilmu Pendidikan, Universitas Negeri Surabaya \\ Ekodarminto@unesa.ac.id
}

\begin{abstract}
Abstrak
Lingkup sosial yang semakin tidak terbatas membuat remaja kurang memegang teguh aturan dan norma yang berlaku di masyarakat sehingga menimbulkan etika berperilaku yang kurang baik. Penelitian ini dilatarbelakangi masalah pada peserta didik yang merujuk pada maraknya fenomena menurunnya etika dalam berperilaku pada peserta didik kelas VIII SMP "X" Sidoarjo. Cara bagaimana individu berperilaku dapat diengaruhi oleh sejumlah faktor, antara lain kemampuan berpikir logis dan keterkaitannya dengan nilai kelompok . Berdasarkan latar belakang masalah tersebut tujuan dari penelitian ini adalah untuk mengetahui hubungan antara etika berperilaku dengan kemampuan berpikir logis dan konformitas. Penelitian menggunakan metode kuantitatif dengan sampel penelitian terdiri dari 184 peserta didik kelas VIII SMP "X" Sidoarjo. Penelitian ini menggunakan satu alat tes berpikir logis dan dua skala yakni skala etika berperilaku dan skala konformitas. Analisis data yang digunakan adalah korelasi Kendall's tau-b untuk menguji hubungan dua variabel dan korelasi Kendall-W test untuk menguji hubungan tiga variabel. Hasil dari analisis data korelasi Kendall's tau-b antara kemampuan berpikir logis dan etika berperilaku menunjukkan taraf signifikansi 0,161, konformitas dengan etika berperilaku menunjukkan taraf signifikansi 0,019. Hasil analisis data korelasi Kendall's tau-b antara kemampuan berpikir logis dan konformitas menunjukkan taraf signifikansi 0,017. Hasil analisis korelasi Kendall-W test secara bersamasama antara tiga variabel menunjukkan nilai signifikansi 0,000 yang menunjukkan bahwa kemampuan berpikir logis dan konformitas secara bersama-sama berhubungan secara signifikan dengan etika berperilaku. Perlu adanya usaha pendampingan dan bimbingan bagi peserta didik agar mecapai perkembangan yang optimal di sekolah dengan tanpa mengesampingkan etika.
\end{abstract}

Kata Kunci:Kemampuan berpfikir logis, konformitas, etika berprilaku

\begin{abstract}
Increasingly limited social scope makes adolescents less adherent to the rules and norms that apply in society, causing etichal behavior that is not good. This research is motivated by a problem in students who refer to the rise of the phenomenon of declining ethics in behavior in students of class VIII SMP " $\mathrm{X}$ " Sidoarjo. Based on the background of the problem, the purpose of this research is to determine the relationship between ethical behavior and logical thinking ability and conformity. The study uses quantitative approach with correlation design. Sample of research consisting of 184 students of class VIII SMP "X" Sidoarjo. Data collected uses one of logical thinking test and two scales namely the ethical behavior scale and the conformity scale. Statictically analyzed using the Kendall's tau-b formula to the test the correlation of two variables and Kendall's W correlation to test te relationship of three variables. The results of Kendall tau-b correlation data analysis between logical thinking ability and ethical behavior show a significance level of 0,0161 , conformity with ethical behavior show a significance level of 0,019 . The results of Kendall's tau-b correlation data analysis between logical thinking ability and conformity show a significance level of 0,017 . The results of Kendall-W correlation analysis together between the three variables show a significance value of 0,000 which indicates that the ability to think logically and conformity together is significantly related to ethical behavior. There is a need for assistance and guidance for students to achieve optimal development in schools without ignoring ethics.
\end{abstract}

Keywords: Logical Thinking Ability, Conformity, Ethical Behavior. 


\section{PENDAHULUAN}

Etika merupakan istilah yang tidak asing lagi bagi setiap orang. Umumnya, Etika dapat diartikan sebagai moral, masyarakat sering mengaitkan etika berperilaku dengan adat istiadat atau kebiasaan yang baik yang berlaku di lingkungan sekitar. Etika berkaitan dengan nilai-nilai tata cara hidup yang baik, aturan hidup yang baik, aturan hidup yang baik dan semua kebiasaan yang dianut dan diwariskan secara turun temurun, Rini dan Intan (2015:3). Permasalahan pendidikan yang akhirakhir ini menjadi kegelisahan pendidik, orang tua, dan masyarakat menurut Shahih Al-Utsaimin (2019). Sehingga sangat penting untuk dikaji dalam sebuah penelitian. Penelitian ini menjadi salah satu bukti bahwa etika sangat penting posisinya dalam ketercapaian pembelajaran.

Berdasarkan studi pendahuluan yang dilakukan oleh peneliti di salah satu SMP "X" di Sidoarjo pada tanggal 13 April 2019 dengan wawancara singkat kepada salah satu guru bimbingan dan konseling, mendapatkan hasil bahwa sering terdapat kasus pelanggaran tata tertib sekolah. Berkaitan dengan hal ini, guru BK mengungkapkan bahwa sebagian besar masalah yang terjadi merupakan masalah yang berkaitan dengan etika berperilaku pada peserta didik. Misalkan mengolok-olok guru, berkelahi, melakukan tindakan asusila di sekolah, bahkan menampar orang tua di sekolah ketika guru BK melakukan klarifikasi terkait pelanggaran dengan orang tua siswa yang bersangkutan. Presentase siswa yang terlibat kasus pada semester 1 adalah sebesar $34 \%$ dari total siswa di sekolah tersebut, dengan $26 \%$ diantaranya terkait dengan etika dan moral siswa. Guru bimbingan dan konseling tersebut juga menambahkan bahwa sebagian besar siswa yang berperilaku kurang baik di sekolah merupakan siswa kelas regular yang bisa dikatakan memiliki pola pikir logis di bawah kelas unggulan.

Pernyataan tersebut didasarkan pada hasil tes IQ yang digunakan dalam pengklasifikasian kelas. Di dalam tes IQ terdapat beberapa pertanyaan yang mengukur kemampuan siswa dalam berpikir logis. Sehingga etika berperilaku peserta didik khususnya di SMP "X" Sidoarjo cenderung dipengaruhi oleh kemampuan berpikir logis. Hal tersebut tersebut didasarkan atas teori Piaget yang menyatakan bahwa "pada tahap operasional formal, egosentrisme remaja yang metafisik perlahan berkurang dan menjadi lebih logis, karena rekonsiliasi antara pemikiran formal dan realitas yang dilakukan", ini mengandung arti bahwa peserta didik Sekolah Menengah Pertama yang berdasarkan pengklasifikasian Piaget masuk dalam tahap operasional formal, seyogyanya sudah mencapai kemampuan berpikir logis yang baik, sehingga dianggap semakin mampu mengendalikan diri dan menyesuaikan dengan norma dan aturan yang berlaku di lingkungan sekitarnya.

Akan tetapi kemampuan mengendalikan diri dan menyesuaikan dengan norma juga identik dengan karakteristik remaja yang cenderung berkelompok. hal ini sesuai dengan pendapat Erikson (dalam Prihardani: 2012) bahwa karakteristik perkembangan yang paling menonjol dari anak usia remaja adalah mencari identitas (identity searching) sekaligus kebingungan dengan identitasnya (identity confusion). Alasan remaja membentuk kelompok adalah ingin menunjukkan jati dirinya, adapula yang ingin menyalurkan minat yang selaras dengan kelompok tersebut. Adanya kelompok tersebut tentu menimbulkan dampak positif dan negatif. Dampak positif terjadi manakala kelompok tersebut mampu berorientasi kepada kegiatan yang produktif dan kreatif. Namun bisa jadi negatif manakala anggota kelompok menganggap aturan kelompoknya paling benar sehingga cenderung menolak terhadap aturan yang berlaku di lingkup sekolah maupun masyarakat.

Hal serupa juga diungkap oleh guru BK bahwasannya peserta didik yang bermasalah umumnya menjalin keterikatan sosial dengan teman yang cukup sering bermasalah juga. Remaja melakukan konformitas kepada teman sebaya tidak hanya perilaku yang ditiru melainkan dalam mengambil keputusan, banyak remaja yang kesulitan memutuskan sesuatu, akan tetapi pertimbangan dari teman sebaya biasanya lebih diperhatikan daripada pertimbangan orang tua. Remaja lebih senang membentuk kelompok-kelompok, seperti komunitas tertentu yang dibentuk berdasarkan kesamaan hobi atau kesamaan pemikiran, sehingga mereka menemukan lingkungan yang sefrekuensi. Lingkungan sekolah menjadi faktor penting terbentuknya moral peserta didik, setelah keluarga. Sebagian besar waktu dihabiskan para peserta didik di lingkungan sekolah. Keterhubungan pada sekolah termasuk pada hubungan dengan teman sebaya menyebabkan situasi cenderung percaya dan mematuhi aturan dan norma kelompok baik berdasarkan tekanan maupun kerelaan (konformitas). Konformitas muncul ketika individu meniru sikap atau perilaku orang lain dikarenakan tekanan yang nyata yang mampu dibayangkan oleh mereka. Terdapat konformitas positif yang mengarah kepada perubahan individu menjadi lebih baik, namun juga ada konformitas negatif yang cenderung mengarah kepada perbuatan negatif dan bahkan melanggar etika. perilaku beretika juga melibatkan pemikiran yang logis untuk memposisikan mana perilaku yang negative dan mana yang positif.

Berpikir logis merupakan proses berbicara dengan dirinya sendiri di dalam batin; mempertimbangkan, merenungkan, menganalisis, membuktikan sesuatu, menunjukkan alasan-alasan, menarik kesimpulan, meneliti suatu jalan pikiran, mencari berbagai hal yang berhubungan satu sama lain, mengapa atau untuk apa sesuatu terjadi, serta membahas suatu realitas (Poespoprodjo, 2011).

Piaget memaparkan bahwa proses kognitif individu seiring dengan pola dan tahap-tahap perkembangannya sesuai dengan usianya. Pola dan tahap ini bersifat hierarki yang memiliki arti bahwa harus dilalui berdasarkan urutan 
tertentu. Piaget membagi tahap-tahap kemampuan berpikir menjadi empat yakni :

\section{a. Tahap Sensorimotori (0-2 Tahun)}

Tahap ini dimulai dari kemampuan individu yang nampak dari aktifitas motorik dan persepsinya yang sederhana. Biasanya akan nampak melalui rangsangan panca indra, senang memperhatikan sesuatu lebih lama, memandang berbeda objek disekitarnya dengan dirinya dan lain sebagainya. Proses kognitif pada tahap ini masih terbilang sangat sederhana.

\section{b. Tahap Praoperasional (2-8 tahun)}

Piaget memaparkan bahwa ketika individu mencapai tahap ini ditandai dengan mulainya penggunaan bahasa isyarat atau bahasa tanda, bisa juga disebut dengan bahasa symbol. Pada tahap ini juga mulai berkembang konsep intuitif atau mengikuti naluri, meskipun masih sangat sederhana. Karakteristik pada tahap ini biasanya ditandai dengan self counter yang sangat menonjol.

\section{c. Tahap Operasional Konkret (7-12 tahun)}

Pada tahap operasional konkret ini, individu mulai menggunakan aturan-aturan yang jelas dan logis, serta ditandai dengan adanya reversible dan kekekalan. Selain itu, individu yang berada di tahap ini juga seharusnya memiliki kecakapan berpikir logis.

\section{d. Tahap Operasional Formal (11-18 tahun)}

Kemampuan berpikir pada tahap ini ditandai dengan semakin berkembangnya pola berpikir logis dan abstrak. Selain itu, individu juga sudah mampu mengembangkan hipotesa, menafsirkan serta menarik kesimpulan. Hal tersebut apabila dianalogikan dengan etika berperilaku. Maka dapat dikatakan, apabila individu telah mencapai tahap ini sudah seyogyanya mampu mengembangkan hipotesa atau memunculkan praduga sementara dari akibat jika dia melakukan perbuatan yang melanggar norma moral. Selanjutnya individu pun mampu menafsirkan atau mengartikan aturan moral yang berlaku di lingkungan sekitar untuk dimengerti atau dipahami serta diimplementasikan didalam perilakunya agar sesuai dengan moral yang berlaku. Seperti yang kita ketahui bahwa dalam bersosialisasi juga diperlukan etika yang sesuai. Apalagi dalam sebuah lingkup sosial, utamanya peserta didik yang umumnya mempunyai keterhubungan dengan sebayanya (konformitas).

Konformitas merupakan suatu perintah yang bisa jadi dianggap tuntutan dari teman sebaya terhadap anggotanya. Menurut Zebua dan Nurdjayadi (Lestari, 2016) Konformitas umumnya memiliki penaruh yang cukup kuat sehingga dapat menyebabkan munculnya perilaku-perilaku tertentu pada anggota kelompok. Pendapat yang sedikit berbeda diungkapkan Chaplin (2010) yang mengatakan bahwa konformitas merupakan kecenderungan untuk dipengaruhi oleh tekanan kelompok serta tidak menentang norma-norma yang ditetapkan dalam kelompok tersebut.

Sebuah perilaku dikatakan konformitas jika individu lebih banyak menyukai dan sepakat dengan pendapat (pandangan), perilaku, dan penampilan kelompok tersebut sehingga cenderung melakukan atau menirunya. Menurut Setiawati \& Damayanti (2013), usia remaja sering disebut dengan usia pencarian jati diri sehingga semakin banyak individu mengalami krisis identitas. Krisis identitas yang marak terjadi saat ini adalah perilaku individu terutama yang mendekati remaja semakin beragam dan seolah-olah menggambarkan semakin pudarnya nilai moral di kalangan remaja. Bahkan perilakunya sering merugikan dan mengganggu keamanan masyarakat dengan berbagai perilaku yang menyimpang.

Myers (2012) mengemukakan bahwa konformitas adalah perubahan perilaku atau kepercayaan seseorang sebagai akibat dari tekanan yang diperoleh dari kelompok yang terdiri dari dua jenis yaitu :

1) Pemenuhan, pada dasarnya di luar mengikuti apa yang dilakukan kelompok, namun di dalam hati tidak menyetuji hal tersebut yang biasa disebut kepatuhan. Arti dari pemenuhan dalam konformitas adalah di mana perilaku seseorang sesuai dengan tekanan kelompok sementara secara pribadi orang yang bersangkutan tidak menyetujui perilaku tersebut.

2) Penerimaan, yaitu meyakini dan juga melakukan sesuai dengan yang diperoleh dari tekanan yang berasal dari kelompok. Penerimaan juga dapat dikatakan sebagai bentuk konformitas dimana perilaku keyakinan seseorang sesuai dengan tekanan sosial. Dalam kehidupan seharihari manusia tumbuh dan berkembang di dalam lingkungan sosial.

Dalam rangka tumbuh dan berkembang di lingkungan sosial, manusia perlu memahmi dan menerapkan etika berperilaku. Menurut Ahmad Amin (2012) etika yakni ilmu pengetahuan yang menjelaskan arti baik dan buruk, menerangkan apa yang seharusnya dilakukan oleh manusia, menyatakan tujuan yang harus dicapai oleh manusia dalam perbuatan mereka, dan menunjukkan jalan untuk melakukan apa yang seharusnya dilakukan oleh manusia utamanya dalam berperilaku. Suatu perilaku dikatakan benar untuk satu konteks budaya tertentu namun bisa saja kurang tepat menurut konteks budaya yang lain. Oleh karena itu dalam konteks ini, norma budaya akan ditimbang menurut kriteria umum (universal), yakni suatu pandangan umum yang diakui oleh masyarakat dari berbagai budaya tentang perilaku yang dinilai benar atau salah, dalam hal ini norma budaya masyarakat Jawa Timur pada umumnya. Seperti yang dikemukakan Endraswara (2010) bahwa dalam pergaulan sehari-hari di sekolah siswa hendaknya mengucapkan salam terhadap teman dan guru, saling menghormati antar 
sesama, menyampaikan pendapat secara sopan dan tidak menyinggung perasaan orang lain, membiasakan diri mengucapkan terimakasih dan meminta maaf apabila melakukan kesalahan, serta menggunakan bahasa yang sopan dan beradap dalam membedakan hubungan dengan orang lain yang lebih tua dan teman sejawat, dan tidak menggunakan kata-kata kotor dan kasar, cacian, dan pornografi.

Kohlberg mengemukakan bahwa Individu dengan tingkat penalaran moral yang tinggi cenderung memiliki kemampuan berpikir logis yang tinggi juga untuk melakukan suatu tindakan tertentu, terutama yang berkaitan dengan dilema etika. Kohlberg memahami bahwa terdapat tiga tingkatan dan enam tahapan perkembangan kesadaran moral yakni :

1) Pra-konvensional, pada tingkat ini anak mulai mengakui adanya aturan-aturan tentang baik dan buruk, terdapat reaksi terhadap ungkapan-ungkapan budaya mengenai baik dan buruk, benar dan salah. Motivasi untuk penilaian moral terhadap perbuatan didasari atas hukuman atau pujian, hal yang menyenangkan atau tidak menyenangkan.

2) Konvensinal, pada tingkat ini, perubahan mulai dinilai atas dasar norma-norma umum dan kewajiban serta otoritas dijunjung tinggi. Disebut tingkat konvensional sebab anak mulai menyesuaikan penilaian dan perilakunya dengan harapan orang lain atau aturan yang berlaku dalam kelompok sosialnya..

3) Pasca konvensional, tingkat ini sering disebut juga tingkat "otonom" atau tingkat "berprinsip", sebab hidup moral dipandang sebagai penerimaan tanggungjawab pribadi atas dasar prinsip-prinsip yang dianut dalam batin. Norma-norma yang ditemukan dalam masyarakat tidak dengan sendirinya diterima, tapi dinilai berdasarkan prinsip-prinsip yang bertumbuh dari kebebasan individual.

Berdasarkan penjelasan tersebut diatas, Peneliti tertarik untuk melakukan penelitian berkaitan dengan etika berperilaku dikarenakan hakikat pendidikan bukan hanya sekedar pembelajaran, namun juga terkait dengan terbentuknya karakter yang baik pada diri peserta didik. Selain itu, peneliti memilih SMP " $X$ " di Sidoarjo sebagai subjek penelitian dikarenakan berdasarkan studi pendahuluan tersebut, di SMP "X" di Sidoarjo memenuhi beberapa indikator yang dirasa tepat untuk dilakukan penelitian ini. Melihat adanya keterkaitan tersebut, tujuan dari penelitian ini yaitu untuk (1) Mengumpulkan dan menganilis data tentang hubungan antara etika berperilaku dengan kemampuan berpikir logis pada siswa Sekolah Menengah Pertama (SMP) di Sidoarjo, Mengumpulkan dan menganilis data tentang hubungan antara etika berperilaku dengan konformitas pada siswa Sekolah Menengah Pertama (SMP) di Sidoarjo, (3)
Mengumpulkan dan menganilis data tentang hubungan antara kemampuan berpikir logis dengan konformitas pada siswa Sekolah Menengah Pertama (SMP) di Sidoarjo (4) Mengumpulkan dan menganilis data tentang hubungan antara etika berperilaku dengan kemampuan berpikir logis dan konformitas pada siswa Sekolah Menengah Pertama (SMP) di Sidoarjo.

\section{METODE}

Penelitian ini dilaksanakan melalui pendekatan kuantitatif dengan rancangan korelasional.

Populasi penelitian ini adalah siswa kelas VIII di SMP "X" Sidoarjo. Sampel yang digunakan dihitung menggunakan metode Slovin dengan rumus sebagai berikut :

$$
\begin{aligned}
& n=\frac{\mathbb{N}}{1+N e^{2}} \\
& \text { Keterangan }: \\
& \mathrm{n}=\text { Sampel } \\
& \mathrm{N}=\text { Populasi } \\
& \mathrm{e}=\text { Taraf Kesalahan }
\end{aligned}
$$

Berdasarkan perhitungan menggunakan rumus slovin, maka didapatkan hasil sebagai berikut :

$$
\begin{aligned}
& n=\frac{\text { aag }}{1+239(0,05)^{2}} \\
& =183,59
\end{aligned}
$$

Jadi, sampel pada penelitian ini adalah 184 peserta didik dengan pengambilan secara acak yakni dari kelas VIII-A, VIII-B, VIII-C, VIII-D, VIII-E, dan VIII-F. Penelitian ini melibatkan tiga variabel yakni etika berperilaku sebagai variabel terikat, serta konformitas dan kemampuan berpikir logis sebgai variabel bebas. Variabel etika berperilaku (Y) diukur melalui skala etika berperilaku yang dikembangkan sendiri oleh peneliti menggunakan 32 item valid dan telah memiliki koefisien reliabilitas sebesar 0,805. Variabel konformitas $\left(\mathrm{X}_{2}\right)$ diukur dengan skala konformitas yang dikembangkan sendiri oleh peneliti menggunakan 27 item valid dan telah memiliki koefisien reliabilitas sebesar 0,816 . Variabel kemampuan berpikir logis $\left(\mathrm{X}_{1}\right)$ diukur dengan menggunakan tes kemampuan berpikir logis.

Data penelitian dianalisis melalui teknik statistik dengan pendekatan non parametrik yakni rumus kendall's tau-b untuk menguji hubungan antara dua variabel yang tidak berdistribusi normal atau non parametrik, dalam penelitian ini hubungan antara kemampuan berpikir logis $\left(\mathrm{X}_{1}\right)$ dengan etika berperilaku (Y), hubungan antara konformitas $\left(\mathrm{X}_{2}\right)$ dengan etika berperilaku (Y), serta hubungan antara kemampuan berpikir logis $\left(\mathrm{X}_{1}\right)$ dengan konformitas $\left(\mathrm{X}_{2}\right)$. sedangkan rumus korelasi kendall $W$ test untuk mengetahui hubungan antara dua variabel atau lebih secara bersama-sama, yakni hubungan antara kemampuan berpikir logis $\left(\mathrm{X}_{1}\right)$ dan Konformitas $\left(\mathrm{X}_{2}\right)$ dengan Etika Berperilaku (Y). Penggunaan pendekatan non parametrik didasarkan pada hasil uji asumsi yang membuktikan bahwa data tersebut tidak memenuhi asumsi 
parametrik yakni nilai signifikansi pada uji normalitas variabel etika berperilaku sebesar 0,200 (Sig>0,05) yang menunjukkan variabel tersebut tidak berdistribusi normal. Selain itu juga nilai signifikansi pada uji homogenitas sebesar 0,000 $(\mathrm{Sig}<0,05)$ yang menunjukkan bahwa data tidak bersifat homogen.

\section{HASIL DAN PEMBAHASAN}

\section{a. Hasil}

Sebelum melakukan uji statistik inferensial maka dilakukan analisis deskriptif yang menjadi perhitungan awal yang berisi data yang diperoleh dari pengolahan hasil penelitian. Analisis deskriptif adalah bagian dari statistik untuk menggambarkan atau mendeskripsikan data tanpa bermaksud mengeneralisir atau membuat kesimpulan tapi hanya menjelaskan kelompok data itu saja. Berikut Penghitungan analisis deskriptif menggunakan SPSS versi 25.0

\section{Tabel 1. Analisis Deskriptif Descriptive Statistics}

\begin{tabular}{cc|r|r|r|r} 
& & \multicolumn{3}{|c|}{$\begin{array}{c}\text { Std. } \\
\text { Devia }\end{array}$} & \\
& $\mathrm{N}$ & Mean & \multicolumn{1}{|c|}{ tion } & \multicolumn{1}{c|}{ Min } & Max \\
\hline Etika & 184 & 98.67 & 9.46 & 68.00 & 121.00 \\
\hline $\begin{array}{c}\text { Konform } \\
\text { itas }\end{array}$ & 184 & 66.08 & 6.99 & 34.00 & 84.00 \\
\hline $\begin{array}{c}\text { Berpikir } \\
\text { Logis }\end{array}$ & 184 & 307.88 & 305.0 & - & 875.00 \\
\hline
\end{tabular}

Berdasarkan tabel 1, dapat diketahui bahwa data variabel kemampuan berpikir logis $\left(\mathrm{X}_{1}\right)$ yang terdiri dari 10 item soal memiliki nilai diantara $-12,5$ dan 87,5 dengan rata-rata (Mean) sebesar 30,788 serta simpangan baku (standar deviasi) sebesar 3,05. Sedangkan data variabel konformitas $\left(\mathrm{X}_{2}\right)$ yang terdiri dari 27 item memiliki nilai diantara 34 dan 84 dengan rata-rata sebesar 66,076 serta simpangan baku (standar deviasi) sebesar 6,993. Adapun data variabel etika berperilaku (Y) yang terdiri dari 32 item memiliki nilai diantara 68 dan 121 dengan ratarata 98,673 serta simpangan baku (standar deviasi) sebesar 9,463.

Setelah dilakukan analisa deskriptif pada data penelitian, maka selanjutnya diperlukan uji asumsi sebelum melakukan uji hipotesis. Uji asumsi yang digunakan dalam penelitian ini yaitu uji normalitas dan uji homogenitas. Uji normalitas digunakan untuk mengetahui apakah data berdistribusi normal atau tidak, sedangkan uji homogenitas digunakan untuk mengetahui apakah persebaran data homogen atau tidak. Uji normalitas dilakukan dengan menggunakan rumus Kolmogorov-smirnov. Adapun uji homogenitas menggunakan uji Levene, mendapat hasil sebagai berikut :
Tabel 2. Hasil Uji Normalitas One-Sample Kolmogorov-Smirnov Test

\begin{tabular}{|c|c|c|c|c|}
\hline & & $\begin{array}{c}\text { Etika } \\
\text { Berperila } \\
\text { ku }\end{array}$ & $\begin{array}{c}\text { Kemam } \\
\text { puan } \\
\text { Berpikir } \\
\text { Logis } \\
\end{array}$ & $\begin{array}{c}\text { Konfor } \\
\text { mitas }\end{array}$ \\
\hline \multicolumn{2}{|r|}{$\mathrm{N}$} & 184 & 184 & 184 \\
\hline \multirow{2}{*}{$\begin{array}{c}\text { Normal } \\
\text { Paramet } \\
\text { ers }^{\mathrm{a}, \mathrm{b}}\end{array}$} & Mean & 98.67 & 307.88 & 66.07 \\
\hline & $\begin{array}{c}\text { Std. } \\
\text { Deviation }\end{array}$ & 9.46 & 305.04 & 6.99 \\
\hline \multirow{3}{*}{$\begin{array}{c}\text { Most } \\
\text { Extreme } \\
\text { Differen } \\
\text { ces }\end{array}$} & Absolute & .050 & .280 & .093 \\
\hline & Positive & .045 & .280 & .066 \\
\hline & Negative & -.050 & -.193 & -.093 \\
\hline \multicolumn{2}{|c|}{ Test Statistic } & .050 & .280 & .093 \\
\hline \multicolumn{2}{|c|}{$\begin{array}{l}\text { Asymp. Sig. (2- } \\
\text { tailed) }\end{array}$} & $.200^{c, d}$ & $.000^{c}$ & $.001^{\mathrm{c}}$ \\
\hline
\end{tabular}

Dari tabel tersebut dapat diketahui bahwa nilai signifikansi untuk variabel etika berperilaku (Y) sebesar 0,200. Adapun variabel kemampuan berpikir logis $\left(\mathrm{X}_{1}\right)$ sebesar 0,000 dan variabel konformitas $\left(\mathrm{X}_{2}\right)$ sebesar 0,001 . Hal ini dapat disimpulkan bahwa data variabel Y berdistribusi normal karena memiliki nilai signifikansi lebih besar dari 0,05 sedangkan data variabel $\mathrm{X}_{1}$ dan $\mathrm{X}_{2}$ tidak berdistribusi normal karena memiliki nilai signifikansi lebih kecil dari 0,05 .

Tabel 3. Test of Homogeneity of Variances

\begin{tabular}{|c|c|c|c|c|c|}
\hline & & $\begin{array}{l}\text { Levene } \\
\text { Statistic }\end{array}$ & df1 & df2 & Sig. \\
\hline \multirow{4}{*}{$\begin{array}{l}\text { Hasil } \\
\text { penelit } \\
\text { ian }\end{array}$} & Based on Mean & 930.587 & 2 & 549 & .000 \\
\hline & $\begin{array}{l}\text { Based on } \\
\text { Median }\end{array}$ & 198.123 & 2 & 549 & .000 \\
\hline & $\begin{array}{c}\text { Based on } \\
\text { Median and } \\
\text { with adjusted df }\end{array}$ & 198.123 & 2 & $\begin{array}{r}183 . \\
352\end{array}$ & .000 \\
\hline & $\begin{array}{c}\text { Based on } \\
\text { trimmed mean }\end{array}$ & 860.631 & 2 & 549 & .000 \\
\hline
\end{tabular}

Berdasarkan tabel.3 dapat diketahui bahwa nilai signifikansi pada uji homogenitas Levene adalah $0,000($ Sig $<0,05)$. Hal ini dapat disimpulkan bahwa data penelitian ini tidak homogen (heterogen) dikarenakan nilai signifikansinya kurang dari 0,05.

Berdasarkan hasil perhitungan tersebut menunjukkan bahwa sampel berasal dari populasi yang tidak berbentuk distribusi normal dan heterogen, sedangkan tes statistik yang bergantung pada asumsi normalitas menjadi lemah. Maka dalam hal ini sebaiknya uji hipotesis dilakukan dengan menggunakan statistik non parametrik, yaitu uji kendall's tau- $b$. Menurut Sugiyono (2010) uji Kendall's tau-b digunakan karena uji prasyarat tidak terpenuhi, yaitu data yang diperoleh tidak berdistribusi normal dan datanya tidak homogen (heterogen). Uji Kendall's tau-b digunakan untuk menguji ada tidaknya hubungan dari dua variabel, 
sehingga didapatkan hasil sebagai berikut:

Tabel 4. Hasil Uji Korelasi Kendall's tau-b Kemampuan Berpikir Logis $\left(\mathrm{X}_{1}\right)$ dengan Etika Berperilaku (Y) Correlations

\begin{tabular}{|c|c|c|c|c|}
\hline & & & $\begin{array}{l}\text { Kemam } \\
\text { puan } \\
\text { Berpikir } \\
\text { Logis }\end{array}$ & $\begin{array}{c}\text { Etika } \\
\text { Berper } \\
\text { ilaku }\end{array}$ \\
\hline \multirow[t]{6}{*}{$\begin{array}{c}\text { Kendall's } \\
\text { tau_b }\end{array}$} & \multirow[t]{3}{*}{$\begin{array}{l}\text { Kema } \\
\text { mpuan } \\
\text { Berpiki } \\
\text { r Logis }\end{array}$} & $\begin{array}{c}\text { Correlat } \\
\text { ion } \\
\text { Coeffici } \\
\text { ent }\end{array}$ & 1.000 & .075 \\
\hline & & $\begin{array}{l}\text { Sig. (2- } \\
\text { tailed) }\end{array}$ & • & .161 \\
\hline & & $\mathrm{N}$ & 184 & 184 \\
\hline & \multirow[t]{3}{*}{$\begin{array}{c}\text { Etika } \\
\text { Berperi } \\
\text { laku }\end{array}$} & $\begin{array}{c}\text { Correlat } \\
\text { ion } \\
\text { Coeffici } \\
\text { ent }\end{array}$ & .075 & 1.000 \\
\hline & & $\begin{array}{l}\text { Sig. (2- } \\
\text { tailed) }\end{array}$ & .161 & \\
\hline & & $\mathrm{N}$ & 184 & 184 \\
\hline
\end{tabular}

Berdasarkan uji hipotesis pertama menggunakan korelasi Kendall's tau-b dengan menggunakan bantuan SPSS (Statistical Product an Service Solution) versi 25 , menyatakan bahwa tidak terdapat hubungan yang signifikan antara etika berperilaku dengan kemampuan berpikir logis dengan nilai signifikansi 0,161 (Sig > 0,05) yang menunjukkan bahwa tidak terdapat hubungan yang signifikan antara kemampuan berpikir logis dengan etika berperilaku karena memiliki nilai signifikansi lebih dari 0,05 .

Tabel 5. Hasil Uji Korelasi Kendall's tau-b Konformitas ( $\left.\mathbf{X}_{2}\right)$ dengan Etika Berperilaku (Y)

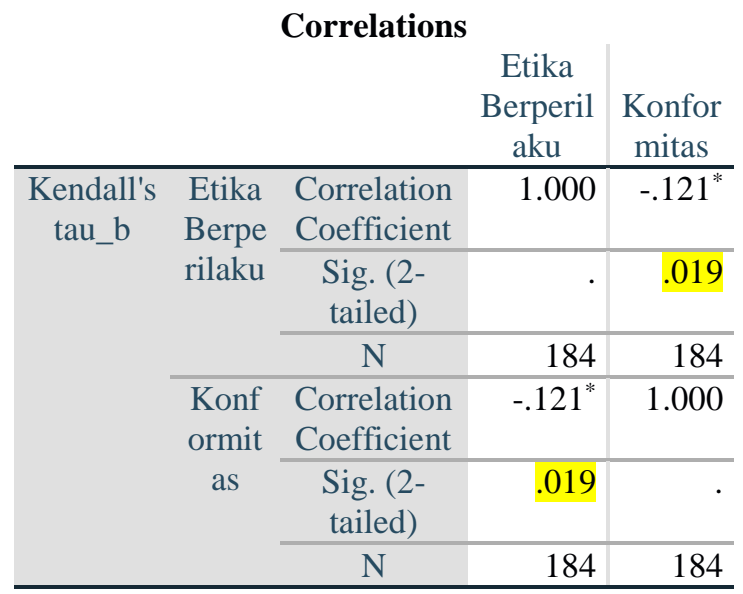

Hasil uji hipotesis kedua menggunakan korelasi Kendall's tau- $b$ dengan menggunakan bantuan SPSS (Statistical Product an Service Solution) versi 25 pada variabel etika berperilaku dengan konformitas menghasilkan nilai 0,019 (Sig < 0,05) yang menunjukkan bahwa terdapat hubungan yang signifikan antara kedua variabel tersebut karena memiliki nilai signifikansi kurang dari 0,05 .

\begin{tabular}{|c|c|c|c|}
\hline \multicolumn{3}{|c|}{$\begin{array}{r}\text { Tabel 6. Hasil Uji Korelasi Ken } \\
\text { Kemampuan Berpikir Logis } \\
\text { Konformitas }\left(\mathbf{X}_{2}\right)\end{array}$} & \\
\hline & & $\begin{array}{l}\text { Kemam } \\
\text { puan } \\
\text { Berpikir } \\
\text { Logis } \\
\end{array}$ & $\begin{array}{c}\text { Konfor } \\
\text { mitas }\end{array}$ \\
\hline \multirow{3}{*}{$\begin{array}{ll}\text { n } & \text { Kema } \\
\text { l's } & \text { mpuan } \\
- & \text { Berpiki } \\
& \text { r Logis }\end{array}$} & $\begin{array}{l}\text { Correlation } \\
\text { Coefficient }\end{array}$ & 1.000 & $-.129^{*}$ \\
\hline & $\begin{array}{l}\text { Sig. (2- } \\
\text { tailed) }\end{array}$ & & .017 \\
\hline & $\mathrm{N}$ & 184 & 184 \\
\hline \multirow[t]{3}{*}{$\begin{array}{c}\text { Konfor } \\
\text { mitas }\end{array}$} & $\begin{array}{l}\text { Correlation } \\
\text { Coefficient }\end{array}$ & $-.129^{*}$ & 1.000 \\
\hline & $\begin{array}{l}\text { Sig. (2- } \\
\text { tailed) }\end{array}$ & .017 & . \\
\hline & $\mathrm{N}$ & 184 & 184 \\
\hline
\end{tabular}

Hasil uji hipotesis ketiga menggunakan korelasi Kendall's tau- $b$ dengan menggunakan bantuan SPSS (Statistical Product an Service Solution) versi 25 pada variabel kemampuan berpikir logis dengan konformitas menghasilkan nilai 0,017 (Sig < 0,05) yang menunjukkan bahwa terdapat hubungan yang signifikan antara kedua variabel tersebut.

Sedangkan untuk hipotesis keempat, menggunakan uji Kendall-W test. uji Kendall-W test adalah teknik statistik non paramterik yang digunakan untuk menguji kelompok data yang memiliki 2 variabel bebas atau lebih yang memiliki distribusi yang tidak mencerminkan adanya parametisitas.

Tabel 7. Uji Kendall-W test Test Statistics

\begin{tabular}{cr}
\hline N & 184 \\
\hline Kendall's W $^{\mathrm{a}}$ & .360 \\
\hline Chi-Square & 132.590 \\
\hline Df & 2 \\
\hline Asymp. Sig. & .000 \\
\hline
\end{tabular}

a. Kendall's Coefficient of Concordance

Berdasarkan uji kendall-W test dengan menggunakan bantuan SPSS (Statistical Product an Service Solution) versi 25 menunjukkan nilai signifikansi 0,000 ( $\mathrm{Sig}<0,05)$ yang menyatakan bahwa terdapat hubungan yang signifikan antara etika berperilaku dengan kemampuan berpikir logis dan konformitas pada siswa Sekolah Menengah Pertama (SMP).

\section{b. Pembahasan}

Berdasarkan hasil perhitungan korelasi Kendall;s tau- $b$ menggunakan SPSS untuk hipotesis pertama diperoleh nilai signifikansi sebesar 0,161 . Nilai 
tersebut lebih besar dari $0,05 \quad($ Sig $>0,05)$ yang menunjukkan bahwa tidak ada hubungan antara kemampuan berpikir logis $\left(\mathrm{X}_{1}\right)$ dengan etika berperilaku (Y). Dengan demikian dinyatakan bahwa tidak terdapat hubungan antara kemampuan berpikir logis dengan etika berperilaku pada siswa Sekolah Menengah Pertama (SMP).

Tidak adanya hubungan antara kemampuan berpikir logis dengan etika berperilaku dapat dipengaruhi oleh berbagai faktor. Salah satunya, pencapaian tahap perkembangan individu sangat variatif antar individu satu dengan lainnya. Ada yang cenderung lebih cepat dan ada yang cenderung lambat Begitupun juga, kemampuan berpikir logis juga akan semakin berpengaruh terhadap penafsiran aturan moral apabila didukung dengan adanya faktor lain diantaranya adanya kesadaran etika. Hal ini juga diungkapkan Abdusshomad (2012) dalam penelitiannya yang menyatakan bahwa faktor-faktor yang mempengaruhi etika diantaranya sifat manusia, aturan agama, dan fenomena kesadaran terhadap etika. Fenomena kesadaran etika berarti sadar tidaknya individu terhadap perilaku sebagai cerminan dari keputusan terhadap sesuatu yang menyangkut kepentingan pribadi serta hak dan kepentingan orang lain. Dilansir dari Koran Republika (2019) mengungkapkan bahwa $50 \%$ remaja mengalami kemerosotan etika. Arus globalisasi dan pengaruh sosial media yang pesat semakin membuat hal-hal yang biasanya dianggap tabuh menjadi challenge bagi generasi milenial sebagai ajang untuk menunjukkan eksistensinya. Semakin marak beredar video-video remaja yang memperlihatkan lekuk tubuh dengan pakaian yang terbuka ditambah gerakan yang kurang pantas dilihat dari segi kesopanan. Selain itu juga sempat beredar video pengeroyokan terhadap guru oleh beberapa siswa di salah satu sekolah di daerah Jawa Timur. Meskipun setelah diklarifikasi bahwa adegan itu hanya merupakan candaan, namun kurang etis jika dilihat dari norma kesopanan. Beberapa hal tersebut menunjukkan bahwa penalaran moral akan semakin mudah diaplikasikan apabila terdapat kesadaran etika dan ketaatan terhadap aturan agama.

Hasil perhitungan korelasi Kendall's tau- $b$ menggunakan SPSS untuk hipotesis yang kedua diperoleh nilai signifikansi 0,019. Nilai tersebut lebih kecil dari 0,05 $(\mathrm{Sig}<0,05)$ yang menunjukkan bahwa terdapat hubungan yang signifikan antara konformitas $\left(\mathrm{X}_{2}\right)$ dengan etika berperilaku $(\mathrm{Y})$. Dengan demikian dapat dinyatakan bahwa terdapat hubungan yang signifikan antara konformitas dengan etika berperilaku pada siswa Sekolah Menengah Pertama (SMP).

Hasil penelitian pada uji hipotesis kedua relevan sebagaimana yang dikemukakan Zebua dan Nurdjayadi (Lestari, 2016) Konformitas umumnya memiliki pengaruh yang cukup kuat sehingga dapat menyebabkan munculnya perilaku-perilaku tertentu pada anggota kelompok. Remaja sebagai tahap perkembangan individu yang cenderung mencari kelompok dan berusaha menunjukkan identitasnya dalam kelompok umumnya akan mematuhi aturan yang berlaku dalam kelompok yang diikutinya.

Akan tetapi perlu diketahui bahwa remaja dalam konformitas akan belajar hubungan timbal balik yang sistematis dan memberikan pengaruh baik itu positif maupun negatif terhadap kehidupan remaja khususnya dalam etika berperilaku. Konformitas atau kecenderungan terhadap tekanan kelompok pada remaja yang bersifat positif contohnya seperti keinginan untuk terlibat dalam aktivitas dengan teman sebaya, berpakaian seperti teman-teman dan keinginan meluangkan waktu untuk menjalin kedekatan yang lebih intens dengan teman sebaya. Adapun konformitas yang bersifat negatif dapat berupa penggunaan bahasa yang jorok, mencuri, merusak, membolos, bahkan mengolok-olok orang tua dan guru. Pada lingkungan pertemanan yang tidak baik atau negatif akan menciptakan konformitas negatif sehingga memunculkan etika perilaku yang negatif. Pernyataan ini diperkuat dengan penelitian yang dilakukan oleh Laksmita (2017), hasil penelitian tersebut menyatakan bahwa terdapat hubungan antara konformitas teman sebaya terhadap perilaku membolos pada remaja SMKN 10 Semarang.

Sementara itu, hasil perhitungan korelasi Kendall' tau- $b$ menggunakan SPSS untuk hipotesis ketiga diperoleh nilai signifikansi 0,017. Nilai tersebut lebih kecil dari 0,05 (Sig<0,05) yang menunjukkan bahwa terdapat hubungan yang signifikan antara kemampuan berpikir logis $\left(\mathrm{X}_{1}\right)$ dan konformitas $\left(\mathrm{X}_{2}\right)$. Dengan demikian dapat dinyatakan bahwa terdapat hubungan yang signifikan antara kemampuan berpikir logis dan konformitas pada siswa Sekolah Menengah Pertama (SMP.

Hasil perhitungan pada hipotesis ketiga relevan sebagaimana yang dikemukakan Setiawan (2015) bahwa kemampuan penalaran mampu melatih siswa untk berpikir logis dalam mengambil suatu kesimpulan baik dari materi pelajaran maupun persoalan yang ada dalam lingkungannya, dalam hal ini kaitannya dalam persoalan memilih kelompok sosial yang nantinya akan membentuk sebuah konformitas. Siswa mempunyai kemampuan logis yang baik, akan mudah memilah mana kelompok yang membawa konformitas positif dan mana kelompok yang membawa konformitas negative.

Sedangkan hasil penelitian untuk hipotesis yang keempat bertujuan untuk mengetahui hubungan yang signifikan antara kemampuan berpikir logis dan konformitas dengan etika berperilaku. Pengujian hipotesis ketiga ini menggunakan uji Kendall-W test. Dari hasil pengujian tersebut didapatkan nilai signifikansi 0,000 (Sig $<0,05$ ) Artinya terdapat hubungan yang signifikan antara kemampuan berpikir logis dan konformitas dengan etika berperilaku pada siswa Sekolah Menengah Pertama (SMP).

Kemampuan berpikir logis dan konformitas yang secara bersama-sama menunjukkan hubungan yang signifikan terhadap etika berperilaku menjadi tugas bagi guru, orang tua dan masyarakat untuk turut mengawal peserta didik. hal ini relevan dengan 
penelitian yang dilakukan oleh Lailatul Maghfiroh (2012) yang mengemukakan bahwa penerapan nilai karakter di sekolah dilakukan dengan menonjolkan nilai kedisiplinan dan menonjolkan nilai religious sehingga mampu meningkatkan kemampuan berpikir logis siswa melalui pengimplementasian ke dalam kurikulum. Seperti yang kita ketahui, permasalahan yang berkaitan dengan etika berperilaku sudah sangat mengkhawatirkan dan memberikan dampak yang negatif utamanya bagi dunia pendidikan di Indonesia. Hal tersebut dapat terjadi karena adanya konformitas yang negatif.

Konformitas yang terjadi pada remaja tidak bisa dipungkiri karena umumnya remaja akan menjalin kedekatan dengan teman sebayanya. Sehingga remaja cenderung mematuhi aturan dan tekanan dalam kelompok. Akan tetapi, tidak semua konformitas berpengaruh negatif, namun adapula yang positif. Oleh karenanya, tahap remaja yang menurut Piaget seyogyanya sudah mencapai tahap operasional formal diharapkan sudah mampu mengembangkan hipotesa, menafsirkan serta menarik kesimpulan. Hal tersebut apabila dianalogikan dengan etika berperilaku. Maka dapat dikatakan, apabila individu telah mencapai tahap ini sudah seyogyanya mampu mengembangkan hipotesa atau memunculkan praduga sementara dari akibat jika dia melakukan perbuatan yang melanggar norma moral.

Praduga sementara dari akibat jika individu melakukan perbuatan melanggar norma yang nantinya mampu menafsirkan atau mengartikan aturan moral yang berlaku di lingkungan sekitar untuk dimengerti atau dipahami serta diimplementasikan didalam perilakunya agar sesuai dengan moral yang berlaku dan memilah konformitas yang negatif dan positif. Oleh karena itu, peran orang tua, guru dan masyarakat sangat diharapkan dalam mengawal dan memberikan pendampingan yang maksimal kepada anak remaja. Terlebih lagi remaja sering menghabiskan waktunya di luar rumah sehingga konformitas dari teman sebaya semakin dominan. Kiruru (2008) mengatakan bahwa ketika anak-anak beranjak remaja, waktu yang diluangkan dengan orangtua lebih sedikit dibandingkan dengan teman sebayanya, dan aturan teman sebayanya menjadi lebih diprioritaskan dan dijadikan acuan daripada aturan yang berlaku di keluarga maupun masyarakat. Sehingga konformitas yang positif memiliki kedudukan yang penting bagi pembentukan etika berperilaku remaja.

Dari penjelasan tersebut, dapat disimpulkan bahwa pada pengujian hipotesis pertama menunjukkan bahwa tidak ada hubungan yang signifikan antara kemampuan berpikir logis dengan etika berperilaku. Sedangkan pada hipotesis kedua menunjukkan bahwa terdapat hubungan yang signifikan antara konformitas dengan etika berperilaku. Sementara itu untuk hipotesis ketiga menunjukkan bahwa terdapat hubungan antara kemampuan berpikir logis dengan konformitas. Sedangkan pada hipotesis keempat menunjukkan terdapat hubungan yang signifikan antara kemampuan berpikir logis dan konformitas dengan etika berperilaku.

\section{PENUTUP}

\section{Simpulan}

Berdasarkan hasil penelitian yang bertujuan untuk mengetahui "Hubungan antara Kemampuan Berpikir Logis dan Konformitas dengan Etika Berperilaku pada siswa Sekolah Menengah Pertama (SMP)" dengan menggunakan 184 sampel dapat dipaparkan kesimpulannya yakni pada pengujian hipotesis pertama ditunjukkan dengan nilai signifikansi 0,161 (Sig>0,05) sehingga tidak terdapat hubungan yang signifikan antara kemampuan berpikir logis dengan etika berperilaku. Pada pengujian hipotesis kedua ditunjukkan dengan nilai signifikansi sebesar 0,019 (Sig<0,05) Sehingga terdapat hubungan yang sinifikan antara konformitas dengan etika berperilaku. Sementara itu pada pengujian hipotesis ketiga ditunjukkan dengan nilai signifikansi sebesar 0,017 $($ Sig $<0,05)$ sehingga terdapat hubungan yang signifikan antara kemampuan berpikir logis dengan konformitas. Sedangkan hasil pengujian hipotesis keempat menggunakan uji Kendall-W test dengan nilai signifikansi 0,000 (Sig<0,05) Artinya terdapat hubungan yang signifikan antara kemampuan berpikir logis dan konformitas dengan etika berperilkaku pada siswa Sekolah Menengah Pertama (SMP).

\section{Saran}

Semoga penelitian ini dapat bermanfaat bagi ilmu pengetahuan pada umumnya dan untuk jurusan bimgingan dan konseling pada khususnya.

\section{DAFTAR PUSTAKA}

Agus Zaenal Fitri. 2012. Pendidikan Karakter Berbasis Nilai dan Etika di Sekolah, Jakarta: Ar-Ruzz Media

Arikunto, S. 2010. Prosedur penelitian suatu pendekatan praktek. Jakarta: Rineka Cipta.

Azwar, Saifuddin. 2013. Metode Penelitian. Yogyakarta: Pustaka Pelajar

Azwar, S. 2014. Reliabilitas dan Validitas Yogyakarta: Pustaka Pelajar

Baron, R.A. dan Byrne, D. 2011. Psikologi sosial. Edisi kesepuluh: jilid 2. Jakarta: Erlangga.

Chaplin, J.P. 2012. Kamus Lengkap Psikologi. Cetakan Keenam. Penerjemah: Kartiko, K. Jakarta : PT. Raja Grafika Persada.

Firmansyah, Iman. 2010. Pengaruh Tingkat Kemampuan berpikir logis Emosional terhadap Prestasi Belajar 
Siswa SMA Triguna Utama Ciputat. Skripsi. Universitas Islam Negeri Syarif Hidayatullah

Gay, L.R,dkk. 2012. Educational Research. New Jersey US : Pearson Education, Inc

Hadi, Sutrisno. 2012. Metodologi Research Jilid 3., Etika Berkeluarga, Bermasyarakat, dan Berpolitik; Tafsir al-Qurean Tematik. Jakarta: Aku Bisa

Handoyo, Pambudi. 2015. Perilaku Menyimpang di Kalangan Remaja pada Masyarakat Karangmojo Plandaan Jombang. Jurnal Ilmu Sosial. Vol 03 (2)

Islamuddin, Haryu. 2012. Psikologi Pendidikan. Yogyakarta: Pustaka Belajar

Khozin, Khazanah. 2013. Pendidikan Agama Islam. Bandung: PT Remaja Rosdakarya,

Martono, Nanang. 2011. Metode Penelitian Kuantitatif. Jakarta: PT. Raya Grafindo Persada

Muhibbin Syah. 2010. Psikologi Pendidikan dengan Pendekatan Baru. Bandung: PT. Remaja Rosdakarya

Muhyiddin Abdusshomad. 2012. Etika Bergaul: ditengah Gelombang Perubahan, Kajian Kitab Kuning. Surabaya: Khalista.

Prihardani. 2012. Hubungan antara Konformitas Geng dengan Kenakalan Remaja. Skripsi. Surakarta: Universitas Muhammadiyah Surakarta.

Rini dan Hanifati Intan. 2015. Etika Profesi dan Pengembangan Peribadi. Jakarta : Erlangga

Ruwanda, Laksmita. 2017. Pengaruh Konfomitas Teman Sebaya terhadap PerilakuMembolos Pada Remaja SMKN 10 Semarang. Skripsi. Semarang: Universitas Negeri Semarang.

Santrock. John W. 2013. Psikologi Pendidikan. Jakarta: Prenada MediaGroup

Setiawati \& Damayanti. 2013. Studi Tentang Perilaku Membolos Pada Siswa SMA Swasta di Surabaya. Jurnal BK Unesa. Vol 03 (1) :456-461

Setiawan. 2015. Peningkatan Kemampuan Penalaran Logis Siswa Melalui Pembelajara Berbasis Masalah. Jurnal Tarbiyah. Vol 04 (2) :3-4

Siregar, S. 2013. Metode penelitian kuantitas: Dilengkapi perbandingan perhitungan manual \& SPSS . Edisi pertama :Jakarta: Kencana Prenada Media Grup.

Sugiyono. 2010. Metode Penelitian Pendidikan Pendekatan Kuantitatif, Kualitatif, dan R\&D.Bandung : Alfabeta.

Sugiyono. 2017. Statistika untuk Penelitian. Bandung : Alfabeta

Sugiyono. 2018. Metode Penelitian Kuantitatif. Bandung: Alfabeta

Suriyani. 2013. Perspektif Perilaku Menyimpang Anak Remaja. Makassar: UIN Alauddin Makassar
Syukriyah, Alfin. 2017. Konsep Pendidikan Moral dan Implikasinya dalam Menekan Tingkat Kenakalan Remaja di MTs An-Nur Gading Winongan Pasuruan. Skripsi. UIN Maulana Malik Ibrahim Malang. 